Session 2249

\title{
A Solar System Project to Promote Renewable Energy Education
}

\author{
Youakim Al Kalaani \\ Northern Illinois University, Technology Department
}

\begin{abstract}
As issues such as climate change, global warming, increased blackouts, and oil price fluctuation continue to pepper the news, it is likely that the use of renewable energy will become an increasing national priority that will affect the next generation of college students. Indeed, a statewide survey conducted by the Illinois Clean Energy Foundation, has found that the vast majority of Illinois residents, from both urban and rural areas, want to see widespread use and development of renewable energy sources such as wind and solar power. However, based on recent local discussions, it is apparent that there is still a widespread lack of understanding about the benefits of using alternative energy sources. As such, there is clearly a need to educate this community and others about sustainable energy and our institution provide the best venue for reaching a large audience in creative and effective ways.
\end{abstract}

This paper presents preliminary efforts and a proposal to implement green energy technical education by developing, testing, and disseminating a 1-kW photovoltaic (PV) power production system recently acquired through a grant. It is anticipated that this project will raise public awareness of the requirement to protect the environment by promoting the use of green energy. The project will also provide a platform to help teach about renewable energy by developing curriculum material with applied projects to boost creativity in students at all levels.

\section{Introduction}

The use of renewable energy is increasing with applications including green power generation for homes, cottage industries, health clinics, and community centers. Illinois has abundant solar and wind resources and students will soon be asking for more curricular support in this area. As issues such as climate change, global warming, increased blackouts, and oil price fluctuation continue to pepper the news ${ }^{1-3}$, it is likely that the use of renewable energy will become an increasing national priority that will affect the next generation of college students ${ }^{4}$. Indeed, a statewide survey ${ }^{5}$ conducted by the Illinois Clean Energy Foundation has found that the vast majority of Illinois residents, from both urban and rural areas, want to see widespread use and development of renewable energy sources such as wind and solar power. However, it is apparent $^{6}$ that there is still a widespread lack of understanding about the benefits of using alternative energy sources. As such, there is clearly a need to educate about sustainable energy 
and our institution provides the best venue for reaching a large audience in creative and effective ways.

An enormous benefit of "green" power is its impact on air quality and other aspects of the environment. According to the US government's Energy Information Administration, over one fourth of the air pollution produced by burning fossil fuels is a by-product of electric power production. Acid rain caused by emissions of sulfur dioxide during the burning of coal and oil, has been reduced in the last 20 years, but has not been completely solved. Installing one kilowatt of solar electric will result in reducing emissions over the course of the 25 -year minimum expected life of the panels, by the following amount ${ }^{7}$ : Carbon dioxide (49,500 pounds); Nitrous oxides (125 pounds), and Sulfur dioxide (400 pounds). It's anticipated that 39,030 pounds of Carbon Dioxide will be saved every year. On average, around 2,615 trees would be required to offset this early emission ${ }^{8}$.

The purpose of this work is to incorporate renewable energy into engineering technology courses at Northern Illinois University (NIU) making use of a solar power generation station recently acquired through a grant from the Foundation for Environmental Education. The solar system will serve as a demonstration platform for educating undergraduate students about contemporary renewable energy theory and technology. Key to this educational strategy is to develop projects that can assist in educating students in all aspects of renewable energy. At least seven electrical engineering technology courses will be affected by this project with estimated annual enrollment of 250 students. The decision to invest in this project is therefore timely and essential.

\section{Project Objectives}

America's schools spend more than $\$ 6$ billion each year on energy. The U.S. Department of Energy (DOE) estimates they could save 25 percent of that money with commonly available energy-efficient and renewable energy technologies ${ }^{9}$. EnergySmart program was launched in 1998 to promote energy education. The initiative is focused on meeting these goals:

- Improve learning and teaching environments

- Reduce energy consumption and costs

- Increase use of clean energy

- Increased energy awareness among students

- Provide instructional material to teach students about the importance of energy conservation and efficiency through hands-on lessons

This project is primarily intended to use a newly installed 1-kW photovoltaic system as an education tool to inform students about the feasibility, reliability, and economics of renewable energy sources. The solar system consists of 8 panels; 125 watt each, mounted in a single row on the roof of Still Hall building which is part of the Technology Department and visible to NIU students and visitors. The power generation data is directly tied into NIU's Internet system where students can have access and able to download information for further investigation and study. 
The objectives of this project will include:

Course Curricula: The project investigator will work to develop curricula and integration into classroom activities. He will study the current literature and best practices of renewable energy as he develop the curriculum and will focus on integrating applied projects that can engage students in creative ways. The following courses will be revised to incorporate renewable energy concepts and applications as follow:

- Electricity and Electronics (TECH175/175A): A new chapter about renewable energy technologies will be added including identification of various system components and learn how to collect system data and perform meter readings.

- Electrical Fundamentals and circuit Analysis (TECH270/270A): The solar system will provide real-time data streams that will be introduced into the classroom via the Internet. Students will examine and analyze on-line electricity production data to calculate hourly and daily amount of green energy produced. They will also calculate the amount of greenhouse emission that would have been released had fossil fuel been used to generate this electricity.

- Electric Machines and Transformers (TECH379/379A): Students will study the operation characteristics of various renewable energy systems. Specific power distributions and circuit protections as applied to solar energy systems will also be introduced and explained.

- Industrial Control Electronics (TECH476): Special topics dealing with power electronics, inverters, actuators, filtering, and data acquisition systems used in renewable energy systems will be thoroughly covered.

Several resources exist to aid teachers in curriculum design. Below is a list of agencies with established programs that could assist in developing renewable energy curriculum in conjunction with the installation of solar or wind power systems:

- The National Renewable Energy Laboratory (NREL) is a Department of Energy lab involved in wind, solar, and other renewable energy field. Their web site has excellent information regarding the various renewable energy sources and an educational resource page at http://www.nrel.gov/education.

- The DOE's Energy Smart Schools program (http://www.eere.energy.gov/energysmartschools) lists guidelines for building energy smart schools and is also an excellent source of information and curriculum building resources.

- Interstate Renewable Energy Council's Schools Going Solar program contains information on other schools installing solar systems (http://irecusa.org/schools/index.html.)

- Solar NOW has a comprehensive educational program dedicated to education in the field of alternative and renewable energy, with an emphasis on PV. As part of its curriculum package for the schools, Solar Now facilitates workshops for teachers, compiles curriculum resources, provides hands-on tools for students, and offers summer internships for high school and college students (http://www.solarnow.org.)

Proceedings of the 2005 American Society for Engineering Education Annual Conference \& Exposition Copyright (C) 2005, American Society for Engineering Education 
A plan of procedure including approximate dates of implementation is given in Table 1 below.

\begin{tabular}{|l|l|l|}
\hline Date & $\begin{array}{l}\text { Course } \\
\text { affected }\end{array}$ & Curriculum and Project developments \\
\hline $\begin{array}{l}\text { February } \\
2005\end{array}$ & TECH175/175A & $\begin{array}{l}\text { Introducing a chapter about renewable energy technologies and student activities to } \\
\text { identify various system components and learn how to collect data and perform/read } \\
\text { instrumentations. }\end{array}$ \\
\hline $\begin{array}{l}\text { March } \\
2005\end{array}$ & TECH270/270A & $\begin{array}{l}\text { Student Projects to collect real-time data streams via the Internet. Students will be } \\
\text { asked to examine and analyze on-line electricity production data to calculate hourly } \\
\text { and daily amount of green energy produced. They will also calculate the amount of } \\
\text { greenhouse emission that would have been released had fossil fuel been used to } \\
\text { generate this electricity }\end{array}$ \\
\hline $\begin{array}{l}\text { April } \\
2005\end{array}$ & TECH379/379A & $\begin{array}{l}\text { Develop course material to study the operation characteristics of various renewable } \\
\text { energy systems. Specific power distributions and circuit protections as applied to } \\
\text { solar energy systems will be introduced and explained. }\end{array}$ \\
\hline $\begin{array}{l}\text { May } \\
2005\end{array}$ & TECH476 & $\begin{array}{l}\text { Special topics dealing with power electronics, inverters, actuators, filtering, and } \\
\text { data acquisition systems used in renewable energy systems will be developed }\end{array}$ \\
\hline
\end{tabular}

Table1. Project Implementation

\section{Project Evaluation}

Student teams in appropriate courses will be formed during the first week of the fall 2005 semester. A pre-designed written document will establish the problem statement, requirements, resources, and grading criterion for the student project. Each team will be required to complete a detailed written report at the end of the semester. They will also be required to render an oral presentation. Student teams should be able to progress to the point of completing their projects by a given date. Students will be expected to conduct research to establish currently available solutions and also acquire knowledge. The instructor will prepare a summary report of this authentic learning experience that will include student evaluations. The students will be expected to rate the proposed experience in positive terms and feel proud of their accomplishment.

\section{Conclusions}

This paper presented an ongoing work to introduce renewable energy education into an electrical engineering program at Northern Illinois University. While renewable energy technologies produce environmentally friendly energy, they can also provide an educational backdrop for students and the community. Students learn about solar energy and then can educate their parents and other adult members of the community about these technologies. The project will thus provide working demonstration examples to students that Illinois has valid potential renewable energy uses in the state and will serve as a business model with market transformation potential. 
The Technology Department at NIU introduces students to diverse and growing areas such as electronics circuits, digital systems, communications, electronics controls, industrial controls, and fiber optics. With the application of computers and software, NIU graduates have the theoretical design and development background in a broad spectrum of areas to handle a wide range of tasks including electronic diagnostics and data analysis. This project will give them a wide variety of system analysis and hands-on skills in renewable energy systems that will make them well prepared to fill a critical need in this growing industry.

\section{References}

1. Beyond Fossil Fuels: How wind, solar and hydrogen will help us end our oil addiction, Sierra, July/August 2002.

2. Sun Power: The global solution for the coming energy crisis, 1995, by Ralph Nansen.

3. Wind Power Generates a Whirl of Interest, IEEE Power Engineering Review, vol 22, No 9, September 2002.

4. Renewable Energy: Its physics, engineering, environmental impacts, economic \& planning, by Bent Sorenson, $2^{\text {nd }}$ Edition, 2000, Academic Press.

5 Illinois Clean Energy Foundation, Overwhelming Public Support in DUPage, Will and Kankakee Counties for Harnessing Clean Energy to Solve Power Problems, Press Release, October 1, 2001.

6. Wind Farm Hearing Draws a Large Crowd, the MidWeek, DeKalb, vol.37, No. 1. January 1, 2003.

7. Illinois Renewable Energy Resources at http://www.illinoisrenew.org/resources/resources.html

8. Renewable Energy and Emission calculation http://www.uni.edu/indtech/eiet

9. DOE Energy Smart Schools at http://www.odod.state.oh.us/cdd/oee/doe_energysmart_schools.htm

\section{Biography}

\section{YOUAKIM Al KALAANI}

Youakim Al Kalaani graduated from Cleveland State University with MS and Doctoral degrees in electrical engineering with a concentration in power systems. He is a member of IEEE and ASEE professional organizations and has research interest in electric power generation, renewable energy, unit scheduling, and optimization. He is currently an Assistant Professor in the Technology Department at Northern Illinois University. 